\title{
Influence of Pressing Temperature on Wood Properties
}

\author{
Maria Romanenko \\ Penza State University of Architecture and Construction, 28 German Titov, Penza, 440028, \\ Russia \\ romanenko.masha@yandex.ru
}

Keywords: Hardwood, Cellulose, Lignin, Amorphous Polymer, Compression, Thermostatted, Density, Wood Processing, Finishing Material

\begin{abstract}
Obtaining wood with high performance properties on the basis of chemical and mechanical action as a result of optimization of technological processes and the use of temperature exposure. The initial raw material is hardwood (aspen, alder), which are little used in construction and in the production of finishing materials. The condition for obtaining wood with high operating properties (increasing density, strength, reducing water saturation, ensuring the dimensional stability of samples for a long time) is the ability of wood as a natural polymer to change properties under the combined effect of temperature and pressure.
\end{abstract}

\section{Introduction}

Aspen and alder are practically not used in the production of building materials such as supporting structures and finishing. Although a feature of aspen wood is the absence of knots, resistance to moisture in the sawn state does not warp, does not crack during drying and storage in the air, but at the same time the wood is prone to drying out and does not have dimensional stability. Alder warps during drying, has moderate hygroscopicity and softness, is resistant to decay, which is why it is often used for equipping wells, as well as storerooms. These types of wood have significant advantages over other hardwoods - they are fast-growing, low purchase prices, low demand in the construction market. To improve the operational properties in 1973 and 1983. researchers have proposed technologies for the heat treatment of wood [1]. Using compression and high temperatures for wood processing, the researchers significantly improved the physical and mechanical properties of samples from beech, larch and pine.

The method of hot pressing of wood treated with formaldehyde resin was widely used [2,3]. It was based on the modification of wood in the form of shavings and sawdust in the production of particle boards. Treated wood with formaldehyde resins or compositions based on them is environmentally hazardous to human life, and since the end of the $80 \mathrm{~s}$ of the 20th century, this technology has been banned from using in Europe and Russia.

Heat treatment of wood at temperatures of $200-280^{\circ} \mathrm{C}$ for $7-12$ hours allows you to increase the density, hardness of the material, but at the same time increases the tendency to brittle fracture under force. Such wood is suitable only for finishing works [4, 5].

Researchers have devoted to the study of the issue of the influence of $1300 \mathrm{C}$ and pressing pressure of $7 \mathrm{MPa}$ on coniferous wood [6,7]. It has been revealed that the technology of obtaining thermally modified wood makes it possible to obtain thermally stabilized wood with increased density, hardness and high water resistance.

\section{Materials, research methodology}

The purpose of the research is to identify the technological features of the production of modified hardwood (aspen, alder) in the Penza region by hot pressing with a force of 6.0 MPa. Press plate temperature $140-160^{\circ} \mathrm{C}$. 
For the study, we used a hot press with a working surface of $600 \times 600 \mathrm{~mm}$ at a maximum pressure of $12 \mathrm{MPa}$.

The wood underwent sawing and finishing to plates with dimensions of $250 \times 250 \times 16 \mathrm{~mm}$. The holding time on the table of a hot press under pressure is $60 \mathrm{~min}$. Table 1 shows the properties of the raw materials and technological regulations.

Table 1. Raw material properties

\begin{tabular}{|c|c|c|c|c|c|c|c|}
\hline № & Wood & $\begin{array}{c}\text { Density, } \\
{\left[\mathrm{k} / \mathrm{m}^{3}\right]}\end{array}$ & $\begin{array}{c}\text { Hardness, } \\
{[\mathrm{MPa}]}\end{array}$ & $\begin{array}{c}\text { Humidity, } \\
{[\%]}\end{array}$ & $\begin{array}{c}\text { Pressing } \\
\text { temperature. } \\
{\left[{ }^{0} \mathrm{C}\right]}\end{array}$ & $\begin{array}{l}\text { Exposure } \\
\text { time, [min.] }\end{array}$ & $\begin{array}{c}\text { Pressing } \\
\text { pressure, } \\
{[\mathrm{MPa}]}\end{array}$ \\
\hline 1 & Aspen & 510 & 23,6 & 3,56 & 140 & \multirow{4}{*}{60} & 12 \\
\hline 2 & Alder & 486 & 27,3 & 4,00 & 140 & & 12 \\
\hline 3 & Aspen & 509 & 23,65 & 3,61 & 160 & & 12 \\
\hline 4 & Alder & 487 & 27,8 & 4,13 & 160 & & 12 \\
\hline
\end{tabular}

Determination of the hardness of wood samples was determined on samples with a size of $50 \times$ $50 \times 50 \mathrm{~mm}$ on a universal testing machine. The hardness of the wood was redistributed in accordance with GOST-16483.17-81, in accordance with the Brinell method. Tests for changes in the characteristics of the environment in the laboratory at a temperature of $+26{ }^{\circ} \mathrm{C}$ and ambient air $\mathrm{W}-56 \%$.

The swelling of the wood was assessed by complete immersion in water for 24 hours, so that the top of the sample was $20-25 \mathrm{~mm}$ high. The temperature of the water in the chamber was automatically maintained at $20{ }^{\circ} \mathrm{C}$.

The original dimensions of the samples before and after the tests were measured with a caliper. The results are in Table 2.

Table 2. Properties of modified materials

\begin{tabular}{|c|c|c|c|c|c|c|c|c|}
\hline \multirow[b]{2}{*}{ № } & \multirow[b]{2}{*}{ Wood } & \multirow{2}{*}{$\begin{array}{c}\text { Reducing } \\
\text { sample } \\
\text { thickness, } \\
{[\%]}\end{array}$} & \multicolumn{2}{|c|}{ Density } & \multicolumn{2}{|c|}{ Hardness } & \multirow{2}{*}{$\begin{array}{c}\text { Pressing } \\
\text { temperature. } \\
{\left[{ }^{0} \mathrm{C}\right]}\end{array}$} & \multirow{2}{*}{$\begin{array}{c}\text { Swelling } \\
\text { value, } \\
{[\%]}\end{array}$} \\
\hline & & & {$\left[\mathrm{kg} / \mathrm{m}^{3}\right]$} & $\begin{array}{l}\text { growth, } \\
{[\%]}\end{array}$ & {$[\mathrm{MPa}]$} & $\begin{array}{l}\text { growth, } \\
{[\%]}\end{array}$ & & \\
\hline 1 & Aspen & 27,3 & 701 & 37,45 & 28,8 & 22,0 & 140 & 6,12 \\
\hline 2 & Alder & 28,4 & 661 & 36,01 & 33,9 & 24,2 & 140 & 7,04 \\
\hline 3 & Aspen & 30,2 & 737 & 44,79 & 28,3 & 19,6 & 160 & 2,98 \\
\hline 4 & Alder & 31,4 & 684 & 40,45 & 32,9 & 18,4 & 160 & 3,56 \\
\hline \multirow{2}{*}{ control } & Aspen & - & - & - & - & - & - & 2,49 \\
\hline & Alder & - & - & - & - & - & - & 2,86 \\
\hline
\end{tabular}

\section{Discussion}

From the analysis of the data obtained (table 2), it can be seen that after the process of hot pressing of hardwood samples, the thickness changed significantly. In aspen and alder, the parameter changes significantly at a pressing temperature of $160^{\circ} \mathrm{C}$ than at $140^{\circ} \mathrm{C}$. 
Swelling also shows that the pressing temperature has a significant effect. So at a pressing temperature of $160{ }^{\circ} \mathrm{C}$, the swelling value is $5,56 \%$ for alder, and 2,98 \% for aspen. At a pressing temperature of $140{ }^{\circ} \mathrm{C}$, the swelling value for alder is $7.04 \%$, for aspen is $6,12 \%$. All hardwood samples that passed swelling tests showed that the control samples have 2,5 times lower values.

The hardness of aspen at a pressing temperature of $140{ }^{\circ} \mathrm{C}$ is greater than at a temperature of $160{ }^{\circ} \mathrm{C}$ by $12,2 \%$, in alder - by $31,5 \%$. At the same time, the increase in wood hardness is higher at lower temperatures. It is possible to explain the processes taking place if we consider the structure and structure of hardwood.

Wood is a composite material consisting of numerous microscopic, layered tubes oriented along the trunk. Cellulose incorporated into the lignin-hemicellulose matrix acts as a reinforcing agent $[8,9]$. The spatial structure of the matrix is formed by interpenetrating networks: 1 - formed by lignin and carbohydrates; 2 - lignin and hemicelluloses; 3 -three-dimensional networks of lignin itself.

It was revealed by a number of researchers that at a relative humidity of wood equal to 27-30 $\%$, cellulose already at $22-26{ }^{\circ} \mathrm{C}$ exhibits the properties of an amorphous-crystalline polymer in a highly elastic state [10-12].

During the experiment, the moisture content of the wood was less than $5 \%$, the temperature of hot pressing was 140 and $160{ }^{\circ} \mathrm{C}$, according to the researchers [10], the glass transition temperature of dry wood ranges from 130 to $190{ }^{\circ} \mathrm{C}$. Thus, the tested wood samples acquired the thermomechanical properties of the intercellular substance. This is a sign of an amorphous polymer with characteristic physical states - glassy, highly elastic and viscous fluid. In this case, the state of the samples is closer to glassy, since the samples are highly fragile. There is no reliable information in the open press about the glass transition temperature of the ligno-carbohydrate complex, and it is not necessary to carry out indirect studies, but rather aimed at understanding the pseudo reticular structure of wood, taking into account the possible volumetric targeted change in the anisotropic structure.

\section{Conclusions}

The studies carried out have shown the possibility of obtaining modified wood with high performance properties. By optimizing the technological process, it is possible to obtain finishing materials with high aesthetic and, most importantly, competitive with respect to rare varieties of wood.

The unique structure of a natural polymer (wood) is endowed with such properties as hydrophilicity, biological compatibility, thermal stability and polyfunctionality, which makes it possible to modify wood not only through mechanical and thermal effects, but also through the use of chemicals and various complexes.

The considered technological method for changing the natural structure of wood makes it possible to obtain wood similar to the texture of plane tree, elm from alder and aspen, provided that the original wood is additionally colored.

The growing need for the development of new and obtaining new cheap materials for construction and finishing purposes is determined by the fact that cellulose, as the main component of wood, is a renewable and rapidly growing raw material.

\section{References}

[1] A. Burmester, Effect of heat-pressure-treatment of semi-dry wood on its dimensional stability. Holz Roh-Werkst, 31 (1973) 237-243. 
[2] E. Giebeler, Dimensional stabilization of wood by moisture-heat-pressure-treatment. Holz RohWerkst, 41 (1983) 87-94. https://doi.org/10.1007/BF02608498

[3] A.J. Stamm, Wood and cellulose science, Ronald Press, New York, USA, 1964.

[4] B. Esteves, A.V. Marques, I. Domingos, H. Pereira, Influence of steam heating on the properties of pine (Pinus pinaster) and eucalypt (Eucalyptus globulus) wood. Wood Science and Technology, 42(3) (2007) 193-207. https://doi.org/10.1007/s00226-006-0099-0

[5] O. Unsal, S.N. Kartal, Z. Candan, R.A. Arango, C.A. Clausen, F. Green, Decay and termite resistance, water absorption and swelling of thermally compressed wood panels. International Biodeterioration \& Biodegradation, 63(5) (2009) 548-552.

https://doi.org/10.1016/j.ibiod.2009.02.001

[6] O. Unsal, S. Korkut, C. Atik, The effect of heat treatment on some properties and colour in eucalyptus (Eucalyptus camaldulensis Dehn.). Wood. 11th International IUFRO Wood Drying Conference - 2010, 398 MADERAS: Ciencia Y Tecnologia Journal, 5(2) (2010) 145-152. https://doi.org/10.4067/S0718-221X2003000200006

[7] V.A. Shamaev, P.A. Smirnov, N.A. Trubnikov, O.A. Kalinin, V.G. Rakhmanov, I.N. Medvedev, E.A. Dolgikh, The main directions of wood. Technology and equipment of woodworking in the XXI century: interuniversity. sat. scientific. tr., VGLTA, Voronezh, (2005) 161-167.

[8] P.P. Erinsh, Study of the structure and destruction of the ligno-carbohydrate matrix of wood. Dis. ... Dr. chem. sciences. Riga, 1976.

[9] P.P. Erinsh, The structure and properties of wood as a multicomponent polymer system. Wood Chemistry, 1 (1977) 8-25.

[10] S.S. Pesetskii, B. Jurkowski, Y.A. Olkhov, O.M. Olkhova, I.P. Storozhuk, U.M. Mozheiko. European Polymer Journal, 37 (2001) 2187-2199. https://doi.org/10.1016/S00143057(01)00120-3

[11] I.I. Romanenko, M.I. Romanenko, Directional modification of the properties of hardwood. Science diary, 11(11) (2017) 19.

[12] I.I. Romanenko, M.I. Romanenko, Modern technologies for the creation of modified wood from hardwood. Ural Scientific Bulletin, 10(2) (2016) 90-95. 